\title{
La clase como construcción: formas de organización y educación de los trabajadores bancarios en Mendoza, Argentina (1969-1974)
}

\author{
The class as construction: forms of organization and education of bank \\ workers in Mendoza, Argentina (1969-1974)
}

\begin{abstract}
Natalia Baraldo*
Resumen: A partir de fuentes orales y documentales, en este artículo reconstruimos momentos claves de la historia y formas de acción colectiva de los trabajadores bancarios de Mendoza, Argentina, durante el período 1969-1974, identificando algunos aprendizajes producidos en el proceso de lucha vinculados a la construcción de una identidad de clase al interior de este colectivo atravesado por la disputa con otras formas de identidad social. Posteriormente, identificamos distintas formas de educación que impulsó el gremio, analizando en profundidad la prensa sindical.
\end{abstract}

Palabras clave: trabajadores bancarios, acción colectiva, identidad, educación, prensa sindical

\begin{abstract}
Based on oral and documentary sources, in this paper we reconstruct key moments in the history and forms of collective action of bank workers from Mendoza, Argentina, during the period 1969-1974, identifying some learnings acquired through the process of struggle related to the construction of a class identity within this group, crossed by the dispute with other forms of social identity. Later, we identified different forms of education that the union promoted, analyzing in depth the trade union press.
\end{abstract}

Key words: bank workers, collective action, identity, education, trade union press.

Recibido: 29 enero 2018

Aceptado: 19 abril 2018 


\section{Apuntes sobre la organización y las luchas de los bancarios}

En este artículo reconstruimos momentos claves de la historia y formas de acción colectiva de los trabajadores bancarios de Mendoza, durante el período 1969-1974 ${ }^{1}$. En ese proceso de luchas, identificamos algunos aprendizajes fundamentales que se asociaron a la construcción de una identidad de clase al interior de este colectivo, atravesado por la disputa con otras formas de identidad social ${ }^{2}$. En un segundo momento, nos abocamos a identificar las distintas formas de educación que impulsó el gremio, considerando tanto los procesos de carácter sistemático, como las iniciativas que, aunque fueron gestadas con otros objetivos, eran consideradas también como formativas por sus protagonistas. Este fue el caso de la prensa sindical y, específicamente, de la revista impulsada por la seccional Mendoza, la cual se analiza con mayor detalle en tanto instrumento pedagógico. La investigación se basó en fuentes orales y documentales.

Antes de comenzar esta aproximación al accionar sindical de los trabajadores bancarios, debe destacarse la ausencia de trabajos específicos que aborden el período aquí estudiado, a excepción de las menciones al mismo que se encuentran en la reconstrucción realizada por la propia Asociación Bancaria $(\mathrm{AB})$ al cumplirse 60 años de vida ${ }^{3}$, y en el

(*) Argentina. Licenciada en Sociología (Universidad Nacional de Cuyo, Mendoza, Argentina) y Doctora en Ciencias de la Educación (Universidad Nacional de Córdoba, Argentina). El presente artículo se basa en nuestra tesis de doctorado realizada con financiamiento del Consejo Nacional de Investigaciones Científicas y Técnicas (CONICET). Correo electrónico: nbaraldobet@ yahoo.com.ar

${ }^{1}$ Este artículo se basa en una investigación más amplia que procuró reconstruir y analizar las formas de organización y educación de las clases subalternas en Argentina durante el período 1969-1976. En la misma se estudiaron distintos casos, entre ellos el de los trabajadores bancarios de Mendoza por ser este sector, responsable de la creación del primer Centro Educativo de Nivel Secundario en dicha provincia, otorgándole sentidos y propósitos que contrastaron con los de la conducción nacional de ese gremio.

2 Entendemos la formación de una identidad de clase como una dimensión del proceso de constitución de una clase para sí, atendiendo a la clásica distinción planteada por Marx. Dicha dimensión hace referencia a la construcción de un nosotros, de una identidad diferenciada respecto a otros grupos sociales, sus representaciones de sí mismos y del mundo social, sus intereses. Este proceso se desarrolla fundamentalmente en las confrontaciones sociales en las que la lucha de clases tiene un papel fundamental. Desde esta perspectiva, la constitución de una identidad social, y en particular de una identidad de clase, constituye un aspecto a observar en el análisis de las formas de conciencia, entre ellas de la conciencia de clase. Para un desarrollo de estos problemas y un análisis específico del sector de la clase trabajadora argentina que protagonizó la recuperación de empresas, ver Julián Rebón La Empresa de la autonomía. Trabajadores recuperando la producción, Colectivo Ediciones y Ediciones PICASO, Buenos Aires, 2007.

${ }_{3}^{3}$ Asociación Bancaria Nacional, 60 años en la vida de un sindicato, sus hombres y el país, Buenos Aires, Secretariado General Nacional, 1984. El mismo constituye una memoria institucional elaborada desde el Secretariado General Nacional, que permite aproximarse al accionar del gremio en distintas etapas, dando cuenta de las iniciativas en diferentes ámbitos de actuación de la entidad, reformas en la estructura organizativa, reivindicaciones, entre otras. No obstante, acentuamos su carácter de memoria institucional en la que puede advertirse la impronta del contexto post-dictadura en el cual fue escrita: la aproximación al período se realiza desde la lectura del pasado reciente conocida como "teoría de los dos demonios". Por otra parte, se trata de una elaboración sobre la historia gremial centrada en los órganos de dirección, en la que el accionar de los cuerpos de delegados y comisiones internas está totalmente ausente. 
trabajo de Marina Kabat referido a las condiciones laborales del sector ${ }^{4}$. Sobre otros períodos, existen contribuciones realizadas por Omar Acha ${ }^{5}$, Nestor Fiorenza ${ }^{6}$, Sergio Onofrio $^{7}$ y Carolina Ramírez ${ }^{8}$; estas dos últimas enfocadas en la Provincia de Mendoza.

Uno de los debates centrales que parece atravesar la historia de las luchas bancarias tiene que ver con la caracterización de su base social: ¿trabajadores o clase media? De acuerdo al estudio de Omar Acha, podemos observar que desde los orígenes de su entidad gremial en 1924, pero especialmente a lo largo de un proceso con centralidad de las grandes huelgas de 1950, 1958 y 1959, los bancarios fueron construyendo una tradición de organización y lucha caracterizada por un gran protagonismo de los organismos de base, un amplio pluralismo ideológico que aun así logró sortear las divisiones y formar filas privilegiando la unidad. Pero lo anterior no se limitó a una defensa sectorial, sino que también fueron asumiendo formas de lucha propias de la clase obrera, formando parte de sus instancias gremiales generales, como la CGT; factores por los que este colectivo social fue integrándose cada vez más a la clase trabajadora argentina. Refiriéndose al triunfo de la huelga bancaria de 1958, durante la gobernación de Aramburu, y a la síntesis de ese proceso en lo que a transformación de la identidad de clase se refiere, dice el autor:

Los bancarios estaban ya integrados a las prácticas y disputas de la clase obrera argentina. Durante la huelga habían irrumpido en manifestaciones callejeras, habían formado piquetes y se habían enfrentado con la policía. Seguían vistiendo de traje y corbata, pero se había profundizado el desplazamiento en el mundo del trabajo que había comenzado durante el peronismo. No se trataba únicamente de imágenes de sí mismos y de prácticas, sino que implicaba un proceso histórico mayor. En efecto, la mecanización del trabajo financiero, si bien había sido lenta en Argentina, condujo a una pérdida del carácter artesanal de las operaciones. Los bancarios eran expropiados de saberes específicos y convertidos cada vez más en proletarios. Mantuvieron sus particularidades del empleo, el vestir y las costumbres, pero ya no eran un sector específico de la clase media. En todo caso, constituían un factor singular de la clase obrera 9 .

\footnotetext{
${ }^{4}$ Marina Kabat, Las condiciones laborales de los trabajadores bancarios argentinos, 1940 a la actualidad, $11^{\circ}$ Congreso Nacional de Estudios del Trabajo, Buenos Aires, UBA, agosto de 2013.

5 Omar Acha, "Curso acelerado para el asalto de bancos", Alejandro Belkin (comp.) Relatos de luchas 1. Contribuciones a la historia del movimiento obrero, Editorial Desde El Subte, Buenos Aires, 2009, 9-27 y Omar Acha, Las huelgas bancarias de Perón a Frondizi (1945-1962). Contribución a la historia de las clases sociales en la Argentina, Ediciones del CCC, Buenos Aires, 2008,

${ }^{6}$ Néstor M. Fiorenza, Los trabajadores de cuello duro y la huelga bancaria de 1959, Editorial El Colectivo, Buenos Aires, 2011.

${ }^{7}$ Sergio Onofrio, Cambios en las relaciones y condiciones laborales en el sector bancario: el caso del Banco Mendoza. Mendoza, Universidad Nacional de Cuyo, Facultad de Ciencias Políticas y Sociales. Tesina de Licenciatura, inédita, 2003.

${ }^{8}$ María Carolina Ramírez, Conflictividad social en Mendoza: el conflicto laboral en un sector clave de la economía. El caso bancario, Mendoza, Universidad Nacional de Cuyo, Facultad de Ciencias Políticas y Sociales. Tesina de Licenciatura, inédita, 2013.

${ }^{9}$ Acha, "Curso acelerado para el asalto de bancos", op. cit., 21-22.
} 
En esa etapa, además de las mencionadas, otra característica que hacía a la identidad de este sector específico de la clase trabajadora era su formación: la mayoría contaba con estudios secundarios y una parte importante comenzaba estudios universitarios ${ }^{10}$. Por otra parte, aunque un segmento de su base social se peronizaría durante los dos primeros gobiernos de ese signo, persistieron en sus filas gran cantidad de activistas de otras orientaciones políticas, con importante presencia de distintas tendencias de izquierda. Aún con lo anterior, en el accionar sindical se privilegió la elección de delegados con representatividad directa en las bases, por sobre las afinidades ideológicas ${ }^{11}$.

Como ha señalado Victoria Basualdo ${ }^{12}$ en su trabajo sobre las comisiones internas ${ }^{13}$, desde mediados de la década de 1960, simultáneamente a la política "integracionista" de la dirigencia sindical comenzaron a hacerse visibles movimientos de oposición. Al contrario de lo ocurrido en los países centrales, dichos movimientos fueron protagonizados en varias oportunidades por sectores de la clase trabajadora caracterizados como "aristocracia obrera" y cuyos principales referentes, en la mayoría de los casos, tuvieron vínculos con distintas corrientes ideológicas de izquierda, incluyendo al interior de ésta a la izquierda peronista $^{14}$. Al poner la mirada en las confrontaciones en el seno del movimiento obrero, la autora identifica dos grandes ejes de debate que atravesaba y dividía tanto a la izquierda como al peronismo: por un lado, un fuerte debate en cuanto a las formas de concebir la relación entre las clases (complementariedad u oposición) y por otro, discusiones en torno a las formas de organización al interior de la clase, expresado en el problema de la

\section{${ }^{10}$ Idem, 9.}

${ }^{11}$ Idem, 27. En un estudio más detallado, dice el autor que las identidades políticas no fueron un obstáculo: "comunistas, peronistas, ucristas, radicales del pueblo, socialistas y democristianos actuaron junto a las bases. Ninguna de las huelgas [...] hubiera ocurrido si las adhesiones peronistas primero, y las fidelidades ucristas después, no se hubieran subordinado a la solidaridad de clase". Omar Acha, Las huelgas bancarias de Perón a Frondizi (1945-1962). Contribución a la historia de las clases sociales en la Argentina, Ediciones del CCC, Buenos Aires, 2008, 222.

${ }^{12}$ Victoria Basualdo, "Los delegados y las comisiones internas en la Historia Argentina: 1943-2007", Daniel Azpiazu, et.al, La industria y el sindicalismo de base en la Argentina, Cara o Ceca, Buenos Aires, 2010, 81157. Esta investigación constituye un gran esfuerzo por sistematizar distintos aportes parciales a fin de poder tener una mirada histórica de largo alcance que va desde 1943 a 2007. En tanto los estudios de caso disponibles en los que se basa la autora se refieren fundamentalmente al sector industrial, la historia de estos órganos de representación está referida principalmente a dicho sector, sin referencias específicas al sector estatal de servicios.

${ }^{13}$ Son instancias de representación directa de los trabajadores en el lugar de trabajo y aparecen referenciadas, aunque en forma vaga, en el Decreto Ley de Asociaciones laborales de 1945. Sintetiza Basualdo: "La comisión interna, también denominada 'comisión interna de reclamos', es un cuerpo colegiado compuesto por un número reducido de delegados que, de acuerdo a los distintos reglamentos internos de las organizaciones sindicales, pueden ser elegidos por la totalidad de los trabajadores del establecimiento por voto simple y directo, o, en su defecto, por los mismos integrantes del cuerpo de delegados. La comisión interna es la encargada de representar a la totalidad de los trabajadores de la fábrica ante la patronal, y de liderar los reclamos obreros vinculados con las condiciones de trabajo, la salubridad, el nivel salarial, incidentes o demandas específicas, entre otros. Al mismo tiempo, estas comisiones internas forman parte de la estructura sindical, y tienen una importante función de articulación entre los trabajadores del establecimiento y el sindicato de base nacional", Ibid, 258.

${ }^{14}$ Ibid, 116-117. 
burocratización de las organizaciones sindicales, los niveles de representatividad y democracia obrera ${ }^{15}$. Estos serán los ejes de la confrontación que a fines de la década de 1960 se dirimía en un campo de batalla: las fábricas y los establecimientos laborales en general; procesos en los cuales "las Comisiones Internas y los delegados, lejos de estar desactivados y fuera de funcionamiento, estaban en el centro de este conflicto" "16. El caso de los trabajadores bancarios ilustra acabadamente lo anterior, como veremos en las páginas que siguen.

\section{Entre la normalización institucional y la reactivación sindical desde los lugares de trabajo}

Durante los primeros años de la dictadura que paradójicamente se autodenominó "Revolución Argentina" (1966-1973), tanto a nivel nacional como provincial La Asociación Bancaria atravesó una etapa de fuertes irregularidades institucionales en la que se intercalaban períodos de intervención al sindicato, llamado a elecciones, "vicios" en los comicios que provocaban nuevas intervenciones y luego, elecciones nuevamente. Luis Piazza, ex delegado del Banco Crédito de $\mathrm{Cuyo}^{17}$, recuerda que inclusive en esos años los comicios se realizaban mediante el voto por correo y con días de antelación. Esta situación interna obstaculizaba la organización por reivindicaciones mínimas. Decía la Revista Claves de Mendoza, sobre el período de la intervención de Alejandro Castro en la seccional: "La actividad sindical en la época de Castro fue nula y 'blanda'. Cuando se decidía un paro, se les comunicaba a los empleados diez minutos antes de tener que cumplirlo, de modo que los paros fracasaban desde el comienzo ${ }^{18}$ ".

De manera que en este período predominó la búsqueda de normalización institucional, la que finalmente se concretaría en Marzo de 1970, cuando la conducción nacional quedó a cargo de Juan Esquerra de la lista "Acuerdo Federación Violeta". Por su parte, desde Agosto de 1971, Armando F. Surballe del "Movimiento Bancarios Unidos" ejercerá la conducción de la seccional Mendoza. Como en otros momentos de la historia del gremio, la nueva dirigencia no era políticamente homogénea. Continuaba la Revista Claves:

Cuando no hubo otra salida, después de 17 meses de intervención, Castro llamó a elecciones, pero prohijó una lista. Sin embargo, ganó otra lista, que se hizo conocer debido al planteo de una serie de reivindicaciones mínimas. En el seno de la lista triunfante no había tampoco unanimidad, sino que se enfrentaban una serie de tendencias, dentro de las que a su vez existían otras diferencias. (...) El sector de la derecha ha ido perdiendo fuerza por la desmembración interna que ha sufrido, mientras que el progresista no puede emprender una labor de fondo por su propia carencia de unidad ideológica ${ }^{19}$.

\footnotetext{
15 Ibid, 122.

16 Ibid, 123.

${ }^{17}$ Entrevista a Luis Piazza, ex Delegado del Banco Crédito de Cuyo, Delegado en la Comisión Nacional de la AB y congresal en Congreso Federal de la Confederación General del Trabajo (CGT).

${ }^{18}$ Revista Claves, N56, 13/10/1972, 15.

${ }^{19}$ Idem.
} 
Simultáneamente con la normalización en el plano institucional, se reactivó fuertemente el activismo de base a través de los cuerpos de delegados y de las Comisiones Internas (en adelante, CI o CGI). Al referirse al proceso de activación en esos años, decía un delegado de Buenos Aires:

Respecto a la politización, los bancos estatales eran muy importantes, sobre todo el [Banco]Nación, el [Banco] Provincia. En el Nación había una conducción burocrática, por asamblea se pide la renuncia, y así entre fines de los sesenta y comienzos de los setenta se renueva la CI formada por compañeros del grupo de Nahuel Moreno. Después esa CI fue más peronista, pero opuesta a la conducción ${ }^{20}$.

Recordemos que en esos años el sector financiero se expandía, concentraba y extranjerizaba cada vez más, pero aún tenían gran importancia las entidades oficiales, de propiedad estatal, entre las que se encontraban: Banco Nación, Industrial e Hipotecario, Caja Nacional de Ahorro Postal e Institución de Servicios Sociales para Bancarios; Banco Mendoza y Banco de Previsión Social, entre otros. Por su parte, el sistema privado de entonces incluía a los siguientes bancos: Unión Comercial e Industrial (BUCI); Agrario Comercial e Industrial; Crédito de Cuyo SA; Hispano Ítalo-Libanés; Regional de Cuyo, Londres y City Bank.

En términos organizativos, en Mendoza aparecían dos cuestiones: por un lado, bancos donde no existían Comisiones Gremiales Internas (CGI) pero sí una embrionaria actividad sindical. Por otro, bancos donde, aun pudiendo constatar su existencia, las mismas se encontraban en manos de direcciones que no respondían a los intereses de los trabajadores. La situación mayoritaria era la primera.

A su vez, en varios bancos se incorporaba nuevo personal, en gran medida jóvenes sin experiencias previas de organización sindical. Por ejemplo, en el Banco de Previsión Social (BPS), entidad enteramente estatal y que por esos años contaba con cerca de 900 empleados, las primeras acciones comenzaron a fines de los años sesenta por cuestiones muy cotidianas que irían construyendo una práctica e identidad como trabajadores, aún antes de constituirse formalmente la primera CGI. Relata Luis Ocaña, quien ingresa a trabajar a ese banco en 1968:

Yo era un administrativo del banco, puesto que tenía el nivel secundario hecho y eso te permitía acceder a una larguísima carrera bancaria que podía terminar en la gerencia o en la cárcel, depende cómo venga la mano. Entonces la cosa era, por un lado, la reivindicación del pago de lo que nos correspondía, por ejemplo no hacer horas extras sin que se nos pagara. Segundo, no permitir abusos porque por ahí a veces eras nuevo, recién entrabas al banco... por ejemplo, un día se me ocurrió y me dejé la barba. Fui a laburar y a la semana me llaman de la gerencia general del banco... [...] Esa imagen del trabajador bancario que te vendían. ¡Llegaban por ejemplo a meterte una sanción disciplinaria a un tipo que llevaba la corbata mal puesta! Por eso es que provocamos: ¿'ah sí? mañana venimos de yean y

\footnotetext{
${ }^{20}$ Entrevista a Andrés Castillo, Delegado general CI La Caja-Bs.As. durante1968-1976. Militante de la
} Juventud Trabajadora Peronista (JTP). 
alpargatas y sin corbata. Vamos a laburar todos así. ¿Qué hacían los tipos? ¿Cerraban el banco? [...] No, tenían que admitirlo. Laburábamos así. Y era divino, porque la gente además sonreía, hacíamos chistes con la misma gente que había dentro del banco, los clientes. $\mathrm{Y}$ estos tipos estaban incinerados, querían vender esta cosa de... yo creo que esto apuntaba a eso: 'está bien, laburamos pero tenemos dignidad'. Y la dignidad no se traduce por la forma de vestir ${ }^{21}$.

Ahora bien: ¿cuál era el eje en torno al cual se planteaban esas primeras acciones que iban construyendo una práctica e identidad colectiva de clase? Continúa el entrevistado:

Se movía de forma muy espontánea y poco esquemática. A ver, suponte, decíamos: a partir de un conflicto personal... más que personal, de un conflicto que alguien vivía personalmente (como el flaco [Pablo] Marín, por ejemplo, condenado a venir a la tarde a laburar solo). Entonces qué hacíamos los demás: ¡‘esto no puede ser!’. Y lo decíamos dos, tres, cuatro, cinco, seis días, 'y no, llamemos a una asamblea, hagamos una asamblea'. ¿'Y cuándo?' 'Y en horario de trabajo, loco'. 'Pero es que esto..., pará, se nos va venir La Bancaria encima'; 'bueno, hablemos con La Bancaria, mirá acá hay un problema...pa, pa pa'. Lo comprometíamos a Surballe en la historia, y no le quedaba otra que decir qué sí ${ }^{22}$.

Entre las acciones relatadas, se encuentran: festejos de aniversarios del banco en el subsuelo del Banco de Previsión Social (BPS) realizados en forma paralela al oficial que organizaba la entidad sólo para algunos empleados; asambleas espontáneas en cada sector; paros con asistencia al lugar de trabajo usando vestimenta informal que desafiaba la tradicional imagen del bancario; acciones de denuncia y resistencia a los abusos patronales como el maltrato, la obligación de trabajar horas extras no pagadas, entre otras. Ese proceso de construcción de una identidad de trabajadores se expresará más adelante en la exigencia a la comisión directiva de la $\mathrm{AB}$ para el llamado a elecciones de Comisiones internas.

Sin embargo, el Banco Mendoza, la entidad semi-estatal más importante de la provincia, presentaba características bien distintas al BPS, tanto por la cantidad de empleados, que rondaban los 1.800, como por la composición de su personal en términos de edad y afinidades ideológicas. Héctor Orelogio, que posteriormente sería elegido delegado general de dicho banco, describe la situación:

En el [Banco] Previsión se daba un poco más por el componente joven y porque había mucha gente más de izquierda y demás, que había entrado a trabajar al banco. Entonces el Previsión vos lo sacabas a la calle. El Nación por ahí, algo de algún banco privado. Y el [Banco] Mendoza vos podías llegar a sacar un $30 \%$ a la calle o $50 \%$, pero el resto no. Pero el resto, ¿qué pasaba? El resto podía apoyar, no es que estaba en contra. Pero era gente conservadora. Es decir, sacarle el saco y la corbata... [...] fue una de las cosas más difíciles de cambiar. Porque a ellos les sacas el saco y la corbata y pierden la identidad...su

\footnotetext{
${ }^{21}$ Entrevista a Luis Ocaña, Delegado del BPS. Militante primero del Peronismo de Base (PB) y luego del Partido Revolucionario de los Trabajadores (PRT)

${ }^{22}$ Idem.
} 
mentalidad. Además, el bancario tendía a ser un tipo que se transforma en un esclavo mental porque tiene seguridad.. ${ }^{23}$

$$
\begin{array}{r}
\text { Paso, paso, paso... } \\
\text { "Para nosotros el sindicato, instrumento de defensa de la clase trabajadora, no } \\
\text { limita su acción en el sentido de sus reivindicaciones inmediatas, sino que al mismo tiempo } \\
\text { interviene en la lucha por las causas revolucionarias del pueblo, del cual forman parte los } \\
\text { bancarios y con el que deben cumplir su rol histórico". } \\
\text { Revista Democracia Sindical } \mathrm{N}^{\circ} 2 \text {, Mendoza, Octubre de } 1973 .
\end{array}
$$

El Cordobazo (1969) marcó un punto de inflexión en el desarrollo de un nuevo sindicalismo que, desde distintas corrientes ideológicas, apelaba a la constante movilización y acción directa desde las bases y a la práctica de la democracia obrera como métodos de construcción de poder por parte de los trabajadores como clase, procurando su independencia respecto a las clases dominantes. En Mendoza, durante los años 1970 y 1971 se agudizaron los conflictos y la movilización de estudiantes y trabajadores (salud, magisterio, contratistas de viña, cementeros), contrastando con la pasividad de la CGT local conducida por el metalúrgico Carlos Fiorentini. En ese proceso se fueron produciendo divisiones que cristalizarán en el surgimiento de nuevos agrupamientos dentro y fuera del peronismo. Por ejemplo, al producirse la división de las 62 Organizaciones (enero de 1971), nacían las 62 "Leales" que se reconocían en los programas obreros de La Falda y Huerta Grande. Por fuera del peronismo, pero planteando la necesidad de unidad como clase, nacía el "Movimiento Intersindical Provincial", que se reconocía en el sindicalismo de liberación cuyo referente era Agustín Tosco, del Sindicato de Luz y Fuerza de Córdoba ${ }^{24}$.

En 1972 recrudecía la lucha de clases, y fue un año clave en la profundización de las diferencias entre tendencias y en los posicionamientos que se irán tomando en consecuencia. Un claro ejemplo, fue lo que sucedió en la conducción de La Asociación Bancaria frente al paro convocado por la CGT para fines de marzo de ese año, en la que se enfrentaron dos tendencias: una "derechista" y otra "progresista", según las palabras de la Revista Claves $^{25}$. Mientras que la 'derechista' proponía un paro por 10 minutos, la tendencia 'progresista' planteó salir a la calle, siendo esta última finalmente la posición triunfadora. Durante esa jornada de lucha, la comisión directiva de La Bancaria fue detenida de conjunto. La primera detención fue la del secretario de Prensa, Pablo Marín, durante una concentración con volanteada en el centro de la ciudad, el día 28 de marzo. Ante esta situación, los bancarios se declararon en estado de alerta y asamblea permanente y denunciaron públicamente "la sistemática persecución de la 'policía brava' del gobierno provincial" y reafirmaron su "irreversible decisión de continuar la lucha por la instauración

${ }^{23}$ Entrevista a Héctor Orelogio, Delegado del Banco Mendoza, militante del Peronismo de Base (PB).

${ }^{24}$ Las referencias al contexto de la Provincia de Mendoza son tomadas en todos los casos de Natalia Baraldo y Gabriela Scodeller, "Un breve contexto para nuestras historias", Baraldo y Scodeller, Mendoza '70. Tierra del sol y de luchas populares, Buenos Aires, Manuel Suárez Editor, 2006.

${ }^{25}$ Revista Claves No80, 6.10.1973. 
de una auténtica justicia social, basada en la organización y movilización del pueblo, a través de la unidad, solidaridad y organización de la clase trabajadora argentina, pilares básicos sobre los que descansa la auténtica liberación nacional y social de nuestra patria" ${ }^{26}$.

Días después se producía el Mendozazo (abril de 1972). Los reclamos no se agotaban en el descontento por el aumento de tarifas eléctricas y del costo de vida, sino que eran más amplios. De acuerdo con Gabriela Scodeller, durante estas emblemáticas jornadas distintos sectores sociales perdieron el miedo y tomaron las calles para cuestionar las formas en que se encontraba organizada la sociedad, el monopolio del poder y de la violencia que ejercía el Estado dictatorial ${ }^{27}$. Junto a obreros, docentes y estudiantes, los bancarios hicieron suyas las calles céntricas, desobedeciendo tanto la represión del régimen como el llamado del secretario general de la CGT a mermar la lucha. El día 4 de abril, encolumnados junto a los obreros del $\mathrm{SMATA}^{28}$ y armándose de improvisados proyectiles, arremetieron contra algunos símbolos del paraíso financiero (City Bank, BUCI, la aseguradora Leng Robert), entre otros sitios-emblemas del poder dominante que encontraron a su paso.. Como consecuencia de este "azo" tuvo que renunciar el gobernador-interventor de la provincia (Francisco Gabrielli) siendo reemplazado por Félix Gibbs, también miembro del Partido Demócrata. Sin embargo, sus efectos no sólo se reflejaron en estos cambios institucionales sino, fundamentalmente, en el plano de la conciencia y la organización de los trabajadores mendocinos. Relata Felipe Cervine, trabajador del BPS que pasaría luego a formar parte de su CGI y a militar en el PST: "Yo me 'desvirgué' políticamente con el Mendozazo. (...) cuando empecé a acercarme a lo gremial, fue luego del Mendozazo -martes 4/4/72- y luego de Ezeiza -20/6/73- cuando rompo con el peronismo, empiezo a leer y a estudiar marxismo. Discuto con todas las tendencias: foquistas, castristas, estalinistas, maoístas, peronistas, etc."29

A la luz de las experiencias revolucionarias asiáticas, europeas y latinoamericanas, los "azos" instalaron la certeza de que un cambio revolucionario era posible en Argentina. Por lo mismo, aceleraron y dinamizaron procesos de radicalización y organización política de estudiantes y trabajadores en general, y muy especialmente de la nueva camada de bancarios que sintetizaban ambas identidades. De manera que muchos comienzan sus experiencias de militancia en diferentes agrupamientos de la Nueva Izquierda de esos años; experiencias que se dieron a veces en forma simultánea y otras veces previamente a la organización sindical, pero que se retroalimentaban mutuamente. Entre las organizaciones emergentes con presencia en bancarios, se encontraron: el ya mencionado Partido Socialista de los Trabajadores (PST), Partido Revolucionario de los Trabajadores (PRT), Peronismo de Base (PB), Juventud Peronista-Montoneros, Partido Comunista Revolucionario (PCR), entre las más significativas.

También los trabajadores de la administración central habían dado un salto organizativo después del Mendozazo creando el Sindicato de Obreros y Empleados

${ }^{26}$ Diario Mendoza, 02.03.1972, 10.

${ }^{27}$ Gabriela Scodeller, "Paso, paso, paso... se viene el Mendozazo", Natalia Baraldo y Gabriela Scodeller, Mendoza '70, pp. cit., 83-100.

${ }^{28}$ Sindicato de Mecánicos y Afines del Trasporte Automotor de la República Argentina.

${ }^{29}$ Entrevista a Felipe Cervine, op. cit. 
Públicos (SOEP). A fines de 1972, el SOEP junto a otros gremios estatales de sectores como Troles, Irrigación y Gráficos formaron una Intersindical ${ }^{30}$, cuya reivindicación común fue la demanda de aumento salarial. La Bancaria se sumó a esta iniciativa en enero de 1973, por mandato de asamblea. El éxito del paro con movilización, efectivizado por la Intersindical durante marzo de 1973, produjo nuevamente la renuncia del gobernador a tan sólo 2 meses de que las nuevas autoridades recientemente electas asumieran el cargo. Pero al igual que ocurrió con el Mendozazo, la importancia de la medida radicó en lo que aportó al avance de la unidad de la clase trabajadora estatal de la provincia, de la que los bancarios se reconocían parte. Durante ese movilizado verano del ' 73 , que ilustra el contexto de creciente politización y protagonismo de los trabajadores desde sus lugares de trabajo, y por iniciativa de estos últimos, la seccional Mendoza inauguraba formalmente su Escuela Sindical Bancaria; un Centro Educativo de Nivel Secundario destinado inicialmente a la capacitación de sus afiliados y familiares.

Pero había un desfasaje. Aun cuando el gremio había tenido una participación activa durante aquellas jornadas provinciales de lucha, y su conducción se posicionaba en consecuencia, la situación interna en octubre de 1972 era descripta del siguiente modo por la Revista Claves:

El próximo paso de la organización de la Asociación es la puesta en marcha de las comisiones internas, que sólo existen en algunos bancos que las han formado por sí solos. En los otros, no se llamó a elecciones cuando se debió hacerlo ni se decide aún hacerlo ahora por esa falta de decisión de los secretarios que aún asisten a las reuniones. Librados a su propia suerte, los afiliados indican como causal de la inoperancia de hoy al letal y efectivo problema de la burocratización $^{31}$.

El nuevo activismo que impulsaría la democratización sindical se forjaba en los bancos al calor de las experiencias liberadoras y clasistas de la época, de los "azos" y de la propia acción entre compañeros de trabajo que mencionamos antes: asambleas, aniversarios del banco paralelos al oficial; paros activos con diversas modalidades, por ejemplo usando vestimenta informal ("jean" y alpargatas"), clases en el subsuelo para terminar la escuela secundaria, entre otras. Decía Luis Ocaña:

eso nos fue formando y fue haciendo que nos juntáramos 10, 15 tipos; y con estas ideas lleváramos la cosa a mayor, en la medida en que las circunstancias también se iban acomodando: 'bueno, pará sí hasta ahora nos salió bien, pero hay Comisiones Internas. ¿Por qué no le decimos al gordo Surballe que llame a elección?'. Evidentemente la patronal, todas las patronales, todos los bancos, presentaron sus propias listas. ¡Y le pasamos por arriba, pero lejos! Por todo este trabajo previo que fue, si vos querés, no hacíamos reuniones extraordinarias, ni de capacitación sindical...sí, evidentemente, nos instruíamos, por ahí nos

\footnotetext{
${ }^{30}$ Para un estudio más profundo de esta experiencia ver Gabriela Scodeller, Conflictos obreros en Mendoza (1969-1974): cambios en las formas de organización y lucha producto del Mendozazo. Un análisis del borramiento del conflicto como política de la memoria de la historiografía regional, Tesis de doctorado, Universidad Nacional de la Plata, 2009.

${ }^{31}$ Revista Claves N`56, 13.10.1972, 15-16.
} 
instruíamos. Nos juntábamos a tomar mate y charlábamos sobre el tema, pero no había un llamado 'a'. Sí, sin embargo, veníamos contagiados, y mucho, por las circunstancias o por el ambiente que se movía o que existía también a nivel nacional; es decir, empezó a aparecer sindicatos como Luz y Fuerza, el Gringo Tosco o Salamanca, etc. etc. entonces reunión, asamblea general de los obreros de IKA Renault en Córdoba... y nos íbamos! $!^{32}$.

Referenciándose en otra corriente del nuevo sindicalismo, H. Orelogio recuerda los intentos del activismo en el caso del Banco Mendoza. Por entonces, militaba también en el Peronismo de Base:

Nosotros en ese proceso estábamos totalmente activos con lo que fue Huerta Grande, la famosa CGTA [CGT de los Argentinos], Raimundo Ongaro.Yo hacía una asamblea y era una clase de filosofía la asamblea... ochocientos tipos y haciendo toda una reflexión; muchos siguiendo el modo de cómo hablaba Ongaro. Entonces vos hacías todo un trabajo que no era simplemente reivindicativo, 'Che muchachos, ganamos poco; bueno, hagamos paro', no. Estábamos a lo mejor 3 horas hablando en una asamblea. Era todo un querer decir, queremos un hombre nuevo, un hombre distinto. No una mera reivindicación salarial que la hacemos dentro de cualquier sistema...el capitalista, el socialista o el que sea [...]. Entonces todo el tema de la solidaridad, de la preocupación por el otro... todas cosas estaban en la base de lo reivindicativo, digamos ${ }^{33}$.

\section{La apertura institucional y los proyectos en disputa}

Con el triunfo del FREJULI (Frente Justicialista de Liberación) en las elecciones de Marzo de 1973, se abría una nueva etapa en Argentina, luego de 18 años donde se habían alternado gobiernos militares y civiles que tuvieron como característica distintiva la proscripción electoral del peronismo y la implementación de medidas económicas que afectaron drásticamente las condiciones de vida de los asalariados. El 25 de mayo de ese año asumía el nuevo gobierno encabezado por Héctor Cámpora y Vicente Solano Lima. En Mendoza asumía como gobernador Alberto Martínez Baca y Carlos Mendoza como vicegobernador, encerrando dicha fórmula las dos facciones en pugna al interior del peronismo $^{34}$.

El enfrentamiento entre las dos fracciones peronistas implicó directamente al movimiento obrero organizado sindicalmente, a raíz de una serie de declaraciones realizadas por el secretario general de la CGT Regional, Carlos Fiorentini, en las que denunciaba la "infiltración marxista" en el gabinete del Gobernador Martínez Baca. Frente a los mismos, la Asociación Bancaria se alineó expresamente a favor del gobernador.

\footnotetext{
32 Entrevista a Luis Ocaña, op. cit.

${ }^{33}$ Entrevista a Héctor Orelogio, op. cit.

${ }^{34}$ A. M. Baca estaba vinculado al sector de la izquierda peronista, mientras que C. Mendoza provenía de los sectores ortodoxos.
} 
Durante junio, el proceso de ocupaciones de edificios públicos y privados que abarcó toda la geografía nacional, no sólo expresó el freno al "continuismo"35, sino que mostró cómo el aparato estatal se convertía en un espacio clave a conquistar y disputar entre las facciones en pugna por distintos proyectos de sociedad. Estudios específicos sobre este proceso realizan un análisis del sector que tuvo la iniciativa y los objetivos que perseguían, en base a lo cual se realiza una distinción entre tomas por "la patria socialista" y tomas por la "patria peronista" ". Mientras algunos ocupaban sus lugares de trabajo para aclamar por "la patria peronista", otros (incluidos los peronistas de izquierda) lo hacían por "la patria socialista".

En Mendoza, los trabajadores del Banco de Previsión Social desconocieron a los directores de esa entidad designados "por el desgobierno de la camarilla militar"37, nombraron autoridades provisorias y realizaron una toma simbólica del banco. En la puerta, los carteles decían: "Hoy comienza el Banco del pueblo"; "Tomamos el Banco para que sea suyo"; "Banco tomado simbólicamente por su personal hasta la asunción de las autoridades designadas por el gobierno popular. Trabajamos normalmente camino hacia la cogestión" "38. En un comunicado explicaban las motivaciones de la medida: "a) demostrar la real vocación de las bases en la dirección de la institución; b) que se nombren compañeros capaces de instrumentar medidas tendientes a lograr la liberación y reconstrucción nacional". Los trabajadores propusieron la formación de una "comisión representativa del personal" que exigía al gobierno provincial la implementación de medidas para que los empleados tengan mayor representación en la dirección de la entidad. Para ello proponían que los directores fueran elegidos por votación directa de las bases y que éstas tuvieran participación real y efectiva en la elaboración de la nueva carta orgánica. Estos y otros puntos fueron aceptados por el gobernador, y el nuevo presidente de la entidad asumió el cargo en una masiva asamblea, en la que expresó "el deseo conjunto de que el banco comience a responder a los intereses de la clase trabajadora". De acuerdo a lo anterior, siguiendo la distinción arriba mencionada, la toma del BPS se encontró entre aquellas que se alinearon a favor de "la patria socialista" "39. Ello expresaba otro hito de los bancarios en el proceso de constitución de su identidad como parte de la clase trabajadora y a favor de un proyecto histórico de carácter anticapitalista

En el plano organizativo se tradujo en la constitución de CI en los bancos donde no existían, así como en la renovación de la composición en las ya existentes; proceso donde las listas afines a las patronales fueron perdiendo terreno en todos los bancos, como

\footnotetext{
35 La dictadura de Lanusse intentó mantenerse en la administración del nuevo gobierno nombrando a funcionarios que garantizaran la "continuidad" política de la dictadura.

${ }^{36}$ Gabriela Scodeller, Conflictos obreros en Mendoza (1969-1974), op. cit.

${ }^{37}$ Diario Mendoza; Mendoza; 12.06.73; p.6.

${ }^{38}$ Idem.

${ }^{39}$ Se trata de las acciones realizadas por la nueva izquierda, con un contenido anticapitalista (aunque con distintos grados de conciencia respecto a ello). Estas "tomas" fueron protagonizadas por organizaciones político- militares o de superficie de izquierda. Aquí se encuentran también las "tomas de las bases" que se alienaron o pueden ser alineadas con ellas. Ver Gabriela Scodeller, "En manos de los trabajadores. Las tomas de junio del '73”, Natalia Baraldo y Gabriela Scodeller (comps.) Mendoza '70. Tierra del Sol y de luchas populares, Manuel Suárez Editor, Buenos Aires, 2006, 129-144.
} 
quedará de manifiesto en la huelga de 1974. Al respecto decía un delegado del BPS que integró la lista ganadora:

Cuando entré al banco -2/6/69- no había interna [Comisión interna]. Nosotros fuimos la primera. La Bancaria a nivel nacional se normalizaba y también las seccionales, entre ellas Mendoza. Creo que te comenté que la nuestra era una seccional muy débil, centrada en la persona de Surballe y que necesitaba de las [comisiones]internas, por eso convoca a elecciones en todos los bancos. Nosotros fuimos elegidos como [comisión]interna el 6/7/73, si no me equivoco. En la revista está la nota. Según el estatuto de la Bancaria, las CGI tenían mandato por dos años con opción a una sola re-elección por un período más. Surballe formó una alianza con Ezquerra, secretario nacional que venía del desarrollismo (Frondizi), y con la tendencia $\mathrm{JP} / \mathrm{M}^{40}$, él era parte de ella. Él no participó en la interna del [Banco] Previsión, aunque quiso manipularla y dirigirla. Trató, en lo posible, que yo no participara, pero me impuse por mi presencia en la base. En las previas de formar la lista para la elección hicimos reuniones con los activistas y en ellas se conformó la lista que integré. Yo iba como Secretario Adjunto. Mario Santos y "Coco" Yáñez como delegados generales; el Quique Rodríguez como Secretario General. La otra lista que se presentó estaba formada por compañeros ligados al personal jerárquico del banco, 'la derecha' como le llamábamos. Ganamos en todas las mesas ${ }^{41}$.

Efectivamente, la nota a la que se hace referencia en el testimonio, reseña que la CI del BPS quedó formalmente constituida en julio de 1973, en comicios donde se enfrentaron 2 listas y participó el 95\% de los empadronados. Resultó ganadora aquella que incluía todas las tendencias de izquierda. En el boletín gremial hay una referencia específica de que esa elección fue resultado de "tres años de trabajo" 42 .

\title{
La "insubordinación" de las bases y el rearme de la burguesía.
}

\author{
"Los grupos o sectores que en cada lugar actúen invocando adhesión al peronismo \\ y al general Perón deberán definirse públicamente en esta situación de guerra contra los \\ grupos marxistas y deberán participar activamente en las acciones que se planifiquen para \\ llevar adelante esta lucha (...) Las orientaciones y directivas que emanen del General Perón \\ en el orden partidario o en función de gobierno serán acatadas, difundidas y sostenidas sin \\ vacilaciones ni discusiones de ninguna clase, y ello como auténtica expresión de la \\ verticalidad que aceptamos los peronistas. \\ "Documento Reservado, \\ Consejo Superior Peronista ${ }^{43}$
}

Las páginas anteriores nos permiten identificar en el accionar de los bancarios una cuestión general de esta etapa: que lejos de aplacarse, la movilización social abierta con el

\footnotetext{
40 Juventud Peronista/Montoneros.

${ }^{41}$ Entrevista a Felipe Cervine, op. cit.

${ }^{42}$ Revista Democracia Sindical, No 2, octubre de 1973, 11.

${ }^{43}$ Citado en Marina Franco, “La 'depuración' interna del peronismo como parte del proceso de construcción del terror de Estado en la Argentina de la década del 70", A Contracorriente, Vol. 8, No. 3, 1011, 23-54. El resaltado es mío.
} 
Cordobazo continuó en 1973, tras la asunción del nuevo gobierno constitucional. Sin embargo, también comenzaron a verse más claramente las diferencias ideológicas y políticas entre sectores. Esto se expresaba en las tensiones al interior del peronismo en el gobierno, pero lo superaba: estaban en disputa distintos proyectos de sociedad. Con los acontecimientos de trascendencia nacional sucedidos ese año ${ }^{44}$, la dirección del Movimiento justicialista -apoyada en el sindicalismo ortodoxo de la conducción de la CGT- se fue posicionando contra el ala radicalizada de su movimiento (la llamada Tendencia Revolucionaria) y contra las experiencias de izquierda en general. Esta posición adquirió su máximo nivel de formulación argumentativa en el "Documento Reservado" del Consejo Superior Peronista, donde se planteaba como tarea urgente la "Depuración ideológica". Como ha investigado Marina Franco, a pesar del carácter reservado que invocaba su nombre, este documento tuvo amplia difusión en los medios masivos de comunicación ${ }^{45}$.

\section{Las huelgas de marzo-abril del ' 74}

A nivel nacional, una de las principales reivindicaciones de los bancarios en esos años era el logro de un escalafón único para todo el gremio, superando la dualidad bancos privados-oficiales. Si bien esta demanda formó parte de los lineamientos discursivos en los inicios de la conducción nacional encabezada por J. Ezquerra ${ }^{46}$, su logro efectivo dependió de la amplia movilización de los trabajadores, en la que tuvieron gran importancia los cuerpos de delegados y las CGI. Aunque esa y otras conquistas se obtendrían finalmente en 1975 con el Convenio Único de actividad (Convenio Colectivo de Trabajo bancario $\mathrm{N}^{\circ} 18 / 75$, actualmente vigente), estuvo precedida por luchas en diferentes seccionales, entre ellas la de Mendoza.

A comienzos de 1974 existían comisiones internas en todos los bancos estatales y privados de la provincia y la mayoría de ellas era conducida por el activismo de izquierda. Recuerda Cervine: “... en las comisiones internas había militantes políticos de diferentes signos, sobre todo de la izquierda. Sin embargo, actuaban como frentes únicos para la acción. Es decir se respetaban las decisiones tomadas por mayoría y se actuaba en cuanto tal" 47 . Por otra parte, los delegados impulsaron una instancia de articulación que potenciaba la acción conjunta de los organismos de base: la Intersindical bancaria. Explicaba L. Ocaña:

Funcionaba de manera... no era tampoco 'la institución', pero metía miedo porque comprometía a muchos bancos. Entonces el gordo [Surballe] por ahí se veía medio amenazado. De todas maneras, siempre concedió. Pero, por ejemplo, nos juntábamos a la

\footnotetext{
${ }^{44}$ Nos referimos a la llamada Masacre de Ezeiza (enfrentamientos durante el intento de retorno a la Argentina del ex presidente Juan D. Perón), a la renuncia de H. Cámpora y el asesinato de José Rucci (representante del sindicalismo ortodoxo).

${ }^{45}$ Marina Franco, op. cit.

${ }^{46}$ Asociación Bancaria, op. cit., 115.

${ }^{47}$ Entrevista a Felipe Cervine, op. cit.
} 
ocasión 'de'; no decíamos 'nos vamos a juntar cada 15 días'. No, surgía un conflicto en un banco, por ejemplo, el Banco Nación, y caíamos ahí: 'che, loco tenemos un problema en el Banco Nación, ta ta ta'. 'Macanudo. ¿Y cuál sería el...?' 'Y el problema acá es las horas extras, ta ta, ta'. 'Ah, bueno y juntémonos'. Nos juntábamos y nos hacíamos solidarios con el banco Nación y hacíamos una huelga que incluía la casi totalidad de los bancos, no sólo el Banco Nación, por el problema del Banco Nación ${ }^{48}$.

En Marzo de 1974 se producía una ola de protestas de los bancarios en todo el país contra la Ley de Prescindibilidad, que amenazaba la estabilidad laboral de los empleados públicos. El despido de 60 empleados de la Casa Central del Banco Nación, desató paros en el resto del país. Y aunque el Ministerio del Interior declaraba ilegales las huelgas de la casa Central argumentando "su carácter extra gremial y subversivo"49, las medidas solidarias se extendían por varios rincones de la geografía nacional. Mendoza no fue ajena a esos procesos. A la solidaridad efectiva con los despedidos se le sumó el reclamo de aumento salarial. El Banco Mendoza, por ejemplo, realizó paros de una hora en demanda de equiparación salarial respecto a Buenos Aires. Héctor Orelogio, delegado general de la CGI de ese banco, expresaba a la prensa: "Sólo pedimos que a igual trabajo obtengamos igual salario que los que se dan en la Capital"50. Mientras la CGI del BPS se hacía presente expresando su solidaridad con el reclamo, la entidad patronal y el Ministerio de Hacienda daban su negativa, alegando que dicho aumento saldría del Pacto Social ${ }^{51}$, aun cuando los empleados plantearon ejemplos de otros aumentos en Buenos Aires que no habían quebrado aquel pacto. A fines de ese mes, la conducción del gremio declaraba la normalización de la actividad, aunque también la continuidad de las gestiones en Buenos Aires por parte del secretariado local para el logro de dicho reclamo.

Aún con lo anterior y como veremos, las discrepancias internas se acentuarán días después, haciéndose explícita la oposición entre gran parte de los órganos de representación en los lugares de trabajo (comisiones gremiales internas) y la conducción gremial. En base a la reconstrucción realizada, nos detenemos entonces en este conflicto, tanto por su significación histórico-política como por la importancia del mismo a la hora de observar aspectos centrales para nuestro análisis.

A comienzos de abril se realizó un plenario en la Asociación Mendocina de Box, para decidir las medidas a tomar en respuesta al reclamo del sector privado de igualación salarial respecto al sector estatal. A dicho reclamo se agregaría el de aumento salarial del conjunto de los bancarios de la provincia, exigiendo la equiparación del salario de todos los bancos al que era percibido por los trabajadores del Banco Central. El Plenario fue presidido por el secretario general y un representante de cada CGI y sus resoluciones fueron: paro por tiempo indeterminado con asambleas informativas en los distintos

\footnotetext{
${ }^{48}$ Entrevista a Luis Ocaña, op. cit.

${ }^{49}$ Diario Eléctrum. Córdoba, 29.03.1974, .4

${ }^{50}$ Diario Mendoza, 15.03.1974, .6.

${ }^{51} \mathrm{El}$ "Acta de compromiso", firmada en junio de 1973 entre gobierno, CGT y CGE (Confederación General Económica), suponía por parte de los trabajadores suspender las negociaciones colectivas por dos años; mientras que el empresariado se comprometía a congelar precios
} 
bancos $^{52}$. Sin embargo, el secretariado en su conjunto, menos dos de sus miembros (los secretarios de Acción Social, José Lozano; y de Prensa y Cultura, Pablo Marín), se retiró del mismo por opinar que el plenario no era representativo. De manera que la asamblea quedó a cargo las CGI, con excepción de la del Banco Mendoza que también se retiró por no estar de acuerdo con las resoluciones tomadas.

La medida de fuerza se prolongó varios días y tuvo una modalidad activa: paro desde las 7hs, concentración en Plaza San Martín desde las 10hs y realización de nuevas asambleas generales. Sobre el grado de acatamiento, recuerda Luis Piazza:

... era muy masivo, muy masivo y de juntar una cantidad de gente grande... ¡cuando nos reuníamos en la Plaza San Martín e íbamos en manifestación hasta la Asociación Mendocina de Box donde se hacían las asambleas todos los días! Con la participación de todos los que estaban ahí, por supuesto. Pero tiene que haber sido fácilmente unas 2000 personas todos los días, eso en 40 días $^{53}[\ldots]$

A través de varias solicitadas, la Comisión Directiva desconoció y condenó la medida de fuerza liderada por el Plenario de Comisiones Gremiales Internas e hizo pública la expulsión del Secretario de Acción Social, José Lozano, que se había plegado al paro. Por esta razón, Pablo Marín presentaba en una asamblea la renuncia a la Secretaría de Prensa y Cultura ${ }^{54}$. Decía otro delegado:

El secretariado dice: no hay huelga, y ellos, el Banco Mendoza responden. Su CI y su cuerpo de delegados no adhiere, porque responde a la conducción del secretariado. Y los demás se revelan todos contra la conducción y se origina este movimiento. Que debe haber sido de lo más grande de la década del 70 dentro del gremio bancario [....] Creo que el problema más grave es que había habido una insubordinación de las CGI y de los delegados, que le habían pasado por encima ${ }^{55}$.

Por su parte, el Plenario de CGI repudió públicamente el accionar de la conducción $^{56}$, y continuó con la medida de fuerza aprobada en el plenario. Sobre el grado de acatamiento, encontramos diferencias al ponderar y contrastar las fuentes orales y documentales. En las primeras encontramos una coincidencia en destacar el carácter "masivo" de la huelga. Los delegados entrevistados recuerdan que sólo el personal del

\footnotetext{
52 Diario Mendoza, 06.04.1974, 2.

${ }^{53}$ Entrevista a Luis Piazza, op. cit.

${ }^{54}$ Entrevista a Felipe Cervine, op. cit.

${ }^{55}$ Idem.

56 “... por la claudicante postura de la Asociación Bancaria, seccional Mendoza, la ASAMBLEA expresa su enérgico repudio a los miembros de la actual conducción que traicionaron a las bases defendiendo los intereses de la patronal y de la burocracia sindical, ignorando con esa actitud, la crítica situación económica de todos los bancarios". Finalmente, en la misma solicitada publicada por Diario Mendoza, el Plenario de CGI concluía en "Llamar a todos los compañeros bancarios a la unidad a fin de lograr nuestros objetivos y solucionar así nuestras necesidades económicas, sirviendo esta UNIDAD para la obtención de todas las reivindicaciones de los trabajadores bancarios". Diario Mendoza 8.04.1974, 7.
} 
Banco Mendoza no se plegó al paro; mientras que la crónica periodística detalla otros bancos oficiales y también privados ${ }^{57}$.

Nos detendremos en algunos momentos claves del desarrollo de la medida de fuerza, basándonos en información de la cobertura periodística, pues permite observar un conflicto intragremial que ha sido ampliamente referenciado en las fuentes orales. Reseñaba Diario Mendoza:

A las 10 se realizó una concentración del personal en huelga en la Plaza San Martín donde fue arengado por varios dirigentes que lo exhortó a mantenerse unidos. De inmediato, encolumnados, los manifestantes se desplazaron por Gutiérrez hasta San Martín. Al pasar frente al Banco de Mendoza, los huelguistas corearon estribillos en los que instaban al personal de la entidad mixta a plegarse al movimiento. Por razones de seguridad, cuando aún no había culminado el horario de atención al público, el Banco de Mendoza cerró sus puertas ${ }^{58}$.

La columna cantaba: "Que sí, que no, Surballe se vendió”; "Luchar, luchar, luchar es la única forma de ganar"; "Se escucha, bancarios en la lucha" y otros similares. Luego la manifestación se dirigió a la Asociación Mendocina de Box donde se realizó la asamblea que ratificó la continuidad del paro. Como vemos, aquí aparece claramente la diferencia con la conducción gremial (personificada en Surballe, secretario general) como así también una tensión con los trabajadores del Banco Mendoza, que en este conflicto se alinearon con la conducción. La crónica sobre una nueva jornada de lucha ilustra aún más lo anterior:

A las 9.50 partió la manifestación, de alrededor de 1500 personas que siguió el siguiente itinerario: Gutiérrez, San Martín, Las Heras y Mitre.

Durante todo el recorrido se entonaron diversos estribillos, tales como: "No somos locos, no somos extremistas, somos obreros que queremos más guita"; "Vea, vea, vea que cosa más bonita, estamos todos juntos por un poco más de guita"; "A la lata, al latero, si no nos dan aumento, esto se pone fulero"; "Bancarios unidos, jamás serán vencidos". Cuando pasaron por las puertas del Banco de Mendoza, que no adhirió a la medida de fuerza, cantaron "Mendoza, hermano, todavía te esperamos" y "Nosotros queremos 90, ustedes se conforman con 30", lo que fue seguido de una fuerte silbatina. Frente al banco de Londres que tampoco adhirió a los paros, repitieron esos estribillos y la silbatina ${ }^{59}$.

En los cantos entonados durante el recorrido se acentúa otro elemento importante, como es la identidad de "clase obrera" y el carácter reivindicativo del reclamo, contraponiéndolos a la caracterización política de "extremista" que formaba parte del

\footnotetext{
57،"La medida tuvo efectividad total en los Bancos de Previsión Social, Unión comercial e industrial, HispanoÍtalo-Libanes, Galicia, De los Andes, Regional de Cuyo y Agrario. Crédito de Cuyo atendió a la clientela en forma parcial, con amplio dispositivo policial. No adhirieron y trabajaron en forma normal: Bancos Nación, Mendoza, Popular, Hipotecario Nacional, Nacional de Desarrollo, De Londres, Español y City". Diario Mendoza, 9.04.74, "Cumpliose ayer parcialmente un paro bancario. Huelguistas fueron intimados a reanudar tareas".

${ }^{58}$ Diario Mendoza, 9.04.1974

${ }^{59}$ Diario Mendoza, 11.04.1974, 7.
} 
repertorio dominante en esa coyuntura de agudización de las medidas persecutorias y represivas hacia el movimiento social y las organizaciones políticas de izquierda ${ }^{60}$. Por otra parte, se interpelaba a los pares del Banco Mendoza y el Banco de Londres a sumarse a la lucha.

Sin embargo, la contraofensiva no tardaría. El 14 de abril, casi al unísono, sus voceros aparecían en la edición del mismo diario que venimos citando ${ }^{61}$. Por un lado, las entidades bancarias privadas emplazaban a los trabajadores de ese sector a levantar la huelga. Por otro, una intimación de la delegación provincial del Ministerio de Trabajo exhortaba al levantamiento de la huelga, so pena de recibir sanciones. Y nuevamente, la posición de la Comisión Directiva de la AB local condenando la medida de fuerza ${ }^{62}$, aunque adhiriendo a las resoluciones del plenario nacional (apoyar la reincorporación de los trabajadores del banco Nación; los reclamos por aumentos salariales, siempre que no atenten contra el Pacto social; la equiparación de sueldos entre empleados del sector privado y estatal).

En este desfavorable contexto, a mediados de abril los trabajadores movilizados realizaron en cada banco sus respectivas asambleas para decidir qué hacer y llevar sus mandatos a un nuevo plenario en la Asociación Mendocina de Box. Continua el ex delegado del Banco Crédito de Cuyo:

... hubo que empezar a negociar cada uno en su banco para volver porque empezaban a haber amenazas de despidos masivos y bueno, estábamos en total infracción de la legislación vigente, había declarado ilegal el paro el Ministerio de trabajo, todo el mundo [...] Inclusive en aquella época, La Caja de Ahorro también tenía una parte de banco, entonces estaban plegados todos a la Bancaria y también participaba ... ¡de la revuelta popular! Y como te digo, se produce el hecho insólito de que primero es el sindicato que declara ilegal el paro y después el Ministerio de Trabajo intima mal [resalta]. Y se nos presentaba el problema de que se pudieran producir despidos masivos; y en eso por lo menos existía una conciencia, no importa cuál fuera la orientación política que tuvieras, existía una conciencia que no podías arriesgar la fuente de trabajo de los compañeros ${ }^{63}$.

Efectivamente, en aquel plenario resolvieron levantar la medida de fuerza para abrir una nueva etapa de negociación, pero también balancearon y sacaron lecciones de la lucha emprendida, expresando al Diario Mendoza:

\footnotetext{
${ }^{60} \mathrm{Al}$ respecto ver Laura Rodríguez Agüero, Ciclo de protestas, experiencias organizativas y represión paraestatal. Mendoza, 1972-1976. Tesis para optar al grado de Doctora en Historia. Universidad Nacional de La Plata, 2013.

${ }^{61}$ Diario Mendoza, 14.04.1974, 4-6.

${ }^{62}$ Lo que estaba en discusión no era el carácter del reclamo (que como se dijo, formaba parte de la plataforma de la $\mathrm{AB}$ a nivel nacional), sino la dirección de la iniciativa; ya que aquello que es denunciado por los directivos del sindicato, en sus propias palabras, se refería a "los movimientos de fuerza parciales por parte de grupos de trabajadores", argumentando que obstaculizaban las gestiones por parte del gremio. Diario Mendoza, 15.04.1974, 4-6.

${ }^{63}$ Entrevista a Luis Piazza, op. cit.
} 
el levantamiento del paro no es una derrota porque ya tenemos un fruto del éxito: la unidad, compatibilidad y organización que caracterizó a este movimiento y que no se registró antes en la historia del gremio bancario'. A la vez se señaló que 'esta tregua servirá para fortificarnos, reorganizarnos y extendernos'. Se agregó que 'otra prueba del éxito obtenido es haber desenmascarado a algunos dirigentes y ahora sabemos quiénes están con las bases y quiénes están en la vereda de enfrente. Distinguimos lo que son los leales dirigentes, la patronal y la burocracia sindical'. También se denunció 'la maniobra del Banco Agrario, que envió un telegrama a una compañera desvinculándola de la institución. Rechazamos esos términos y nos presentamos al Ministerio de Trabajo quien envió un inspector a quien se le negó el paso. Eso determinó una multa para el banco...'. Los presentes aplaudieron de pie, con verdadero furor, cantando la consigna: Bancarios unidos, jamás serán vencidos ${ }^{64}$.

Como puede observarse, además de la unidad y la organización, destacaron un aspecto de interés pedagógico vinculado a otra dimensión fundamental del proceso de construcción de la conciencia de clase: la identificación del adversario y sus formas de acción. Puede observarse, además, que aparecen los dos ejes señalados por V. Basualdo: tanto la lectura sobre las relaciones entre las clases en términos de oposición, como el debate sobre las formas de organización al interior de la clase, expresado en el problema de la "burocracia sindical". Interesa señalar algo más planteado en las resoluciones del plenario, las cuales fueron:

$1^{\circ}$ ) suspender la efectivización de las medidas de fuerza para acceder a la negociación, pedido de la patronal, el tiempo que dure la instancia de negociación $2^{\circ}$ ) dar a las patronales un plazo de 15 días corridos para la conciliación y autorizar a las comisiones gremiales internas para convocar a asambleas con el fin de rever ese plazo, cuando las condiciones lo impongan necesario (...) $3^{\circ}$ ) Realizar hoy martes a las 20 en local $\mathrm{AB}$ un plenario de comisiones gremiales internas para evaluar los resultados de la audiencia de conciliación, que tendrá lugar hoy a las $10.4^{\circ}$ ) Mantener la jornada legal de trabajo de 7 a $14.30 \mathrm{hs} .5^{\circ}$ ) continuar asistiendo a los lugares de trabajo con la ropa que responde a nuestra situación económica $6^{\circ}$ ) Designar a dos miembros de cada CGI para que sean integrados por la $\mathrm{AB}$ como comisión asesora y que asistan a la audiencia de conciliación. $7^{\circ}$ ) Declarar en estado de alerta y movilización a todo el gremio en general. $8^{\circ}$ ) volver mañana (por hoy) a las 7 a los lugares de trabajo habituales. $9^{\circ}$ ) Comprometer por parte de todos los bancos en conflicto un compromiso solidario ante cualquier maniobra de la patronal sobre cualquier compañero ${ }^{65}$.

Profundizando la conciencia sobre el proceso de proletarización del que este colectivo social estaba siendo parte con la creciente mecanización del sistema financiero, aparece en forma permanente, tanto en las fuentes orales como documentales, la insistencia en el cambio de vestimenta: del "traje" (tradicional forma de vestir del bancario, signo de prestigio y diferenciación social respecto a otros sectores asalariados), a la vestimenta informal ("jean y alpargatas") que consideraban acorde a su condición socioeconómica.

\footnotetext{
${ }^{64}$ Diario Mendoza, 16.04.1974, 5.
}

${ }^{65}$ Idem. 


\section{Los bancarios y la educación/ formación}

En el apartado anterior reconstruimos algunos hitos de las luchas y formas de organización de los trabajadores bancarios desde mediados de la década de 1960 hasta el complejo año 1974, visualizando el proceso concreto de formación de una identidad de clase; identificando también disputas ideológicas al interior de este segmento de los trabajadores. Desde la concepción teórica que orienta nuestra investigación, entendemos que la construcción de esa identidad se desarrolla principalmente en los procesos de lucha y en las instancias cotidianas donde se reflexiona sobre ellos y se formaliza un análisis de situación (asambleas, reuniones); procesos enmarcados en una práctica organizativa de carácter colectivo. Consideramos a estos espacios como educativos en un sentido amplio, en tanto allí circulan saberes, conocimientos y se producen aprendizajes, independientemente de que sean reconocidos como tales por sus protagonistas. Sin embargo, como veremos a continuación, La Asociación Bancaria fue un gremio que explícitamente otorgó mucha importancia a la educación en sus distintas formas y niveles.

En lo que sigue, indagamos las prácticas e instrumentos que explícitamente se impulsaron con el objetivo de educar, formar, concientizar; es decir, queremos indagar en los procesos sistemáticos ${ }^{66}$ que impulsaron los bancarios a lo largo del período estudiado. A partir del análisis de distintas fuentes, tanto referidas a la $\mathrm{AB}$ nacional como a la seccional Mendoza, es posible enumerar una serie de iniciativas en esa dirección: a) Cursos de capacitación sindical, b) Charlas sobre temas de actualidad o historia del movimiento obrero, organizadas por los órganos de representación directa en los lugares de trabajo (Comisiones Internas, Cuerpo de Delegados) y/o por agrupaciones político-gremiales, c) Boletines y revistas sindicales, d) Bibliotecas sindicales ${ }^{67}$ e) Centros Educativos de Nivel Secundario los cuales, tanto en Bs. As. como en Mendoza fueron denominados por el sindicato como Escuela Sindical Bancaria $(\mathrm{ESB})^{68}$, y d) hasta un proyecto de Universidad Sindical que no llegó a concretarse ${ }^{69}$.

${ }^{66}$ Norma Michi, Álvaro J. Di Matteo y Diana Vila, "Movimientos populares y procesos formativos", Polifonías. Revista de Educación. Año I, N¹, 2012, 22-41.

${ }^{67}$ La Biblioteca de la sede central de la AB se encuentra cerrada desde 2001. Contaba con 10 mil volúmenes aproximadamente (libros, enciclopedias, colecciones de revistas, etc.); material que fue archivado en un depósito y que sufrió una pérdida importante con una inundación. Otra parte se donó a Cruz Roja. De acuerdo al testimonio recogido, la misma contaba con una sede propia y era ampliamente utilizada por los afiliados y familiares. Además de la sede central, algunas seccionales contaban con bibliotecas propias Fuente: Entrevista a Fabián Frontini, Bibliotecario entre 1990 y 2001. Actualmente se desempeña en la Secretaría de Cultura y Educación.

${ }^{68}$ Una primera aproximación a esta experiencia fue realizada en Natalia Baraldo et. al., "La Escuela Sindical Bancaria: una experiencia de educación secundaria de adultos. Mendoza 1973/1976", Actas II Jornadas Internacionales de Problemas Latinoamericanos: Movimientos Sociales, Procesos Políticos y Conflicto Social: Escenarios de disputa. UNC, Córdoba, 18 al 20 de noviembre de 2010. Profundizamos el estudio del caso en Natalia Baraldo, Educación, organización de las clases subalternas y transformación social en Argentina, op. cit., Capítulo VII.

${ }^{69}$ Hallamos referencias a dos iniciativas diferentes de educación superior: por un lado, un proyecto de universidad construida entre varios sindicatos, que de algún modo recuperara el espíritu de la vieja 
En el caso de la prensa, mientras desde el secretariado nacional se editaba por aquellos años la revista Apertura $^{70}$, desde 1973 la seccional Mendoza lanzaba su Democracia Sindical. A continuación, realizamos un estudio más detallado de ésta última debido a su importancia como instrumento pedagógico.

\title{
La Revista DEMOCRACIA SINDICAL
}

\author{
"Acérquese a nuestra Seccional. Dialogue con los miembros de la Comisión \\ Directiva. Exponga su problema, el que usted quiere que se vea reflejado en la revista. \\ $\mathrm{O}$ el de un compañero. $\mathrm{O}$ el de un sector numeroso. Las páginas de 'Democracia \\ Sindical' le pertenecen. Son un arma valiosa para que el Directorio, el Presidente o el \\ Jefe de Sección vean reflejadas sus arbitrariedades, su enajenación"
}

Democracia Sindical Nº 1,1973

La práctica de democratización que venía ensayándose desde la acción cotidiana en los bancos, se plasmará también en el proyecto comunicacional de la seccional Mendoza. En las páginas que siguen nos focalizaremos en el análisis de la revista Democracia Sindical (en adelante, DS) en su doble carácter de instrumento político-pedagógico y de fuente de información, complementaria de otras fuentes documentales y orales.

Tuvimos acceso a dos ejemplares que habrían sido los únicos ${ }^{71}$, de Mayo y octubre de 1973, respectivamente. Según las fuentes orales, la coordinación del boletín se realizada desde la Secretaría de Prensa y Cultura a través de su secretario, Pablo Marín, aunque de acuerdo a uno de los testimonios, también pasaba por el control del secretario general.

En cuanto a los objetivos, DS se planteaba a la vez como un instrumento de comunicación, denuncia, formación y organización ${ }^{72}$. Un elemento distintivo es el llamado permanente a la participación del conjunto de los trabajadores en cada aspecto de la vida del sindicato y en lo que refiere a la revista, entendiéndola como "un verdadero organismo

Universidad Obrera Nacional; y por otro, una iniciativa realizada exclusivamente desde los bancarios. Sobre la primera, decía el entrevistado: "Había planes muchos más ambiciosos y algunas conversaciones de tratar de establecer realmente una universidad; no nada más para los bancarios sino junto a otros sindicatos para la capacitación de los trabajadores en las distintas áreas. Porque... ya la UTN por ejemplo, bueno a nosotros no nos servía como bancarios que íbamos a ir a estudiar ingeniería, había dejado de ser la universidad de los trabajadores; ya iba cualquiera digamos. Originalmente si vos a la UTN no llevabas el certificado que trabajabas, no ingresabas". Entrevista a Luis Piazza, op. cit.

Sobre la segunda iniciativa, de acuerdo a la fuente documental a la que se tuvo acceso, el 22 de marzo de 1973, la AB inició el expediente de una solicitud de autorización provisoria para la Universidad Sindical Bancaria al Ministerio de Cultura y Educación de la Nación. Dicha solicitud fue aprobada por Decreto 879 del 5 de marzo de 1976, estableciéndose un plazo de un año para obtener la personería jurídica, según lo establecido por la Ley 17.604. Sin embargo, como consecuencia del golpe militar del 24 de marzo de 1976, y de la intervención realizada en dicha entidad gremial, los alcances del mencionado Decreto (879/76) quedaron sin efecto.

${ }^{70}$ Información brindada en Entrevista a Ex Delegado CI Banco Francés-Italiano. También se desempeñó como Secretario de Prensa y Cultura AB sede central.

${ }^{71}$ Uno de los entrevistados mencionó un tercer número que nunca pudo imprimirse por la compleja situación represiva, in crescendo desde 1974 y sus efectos en el activismo gremial.

${ }^{72}$ Revista Democracia Sindical №1, 1973, 2. 
en desarrollo, desde abajo, en las mismas bases donde permanentemente está siendo creado, creciendo en la medida que alcancemos nuevas etapas..."73. Decía uno de los entrevistados, luego de recibir una copia de la Revista:

Me emocioné mucho al reencontrarme con ese proyecto que tuvimos un grupo de activistas sindicales que pretendíamos algo más que un simple noticiero sindical. Quizás, y esto lo pienso ahora, el sacar una revista apuntaba a la 'toma de conciencia' del trabajador. Como habrás visto, el material que pusimos en ella es muy amplio y por lo tanto ecléctico. Ese era, posiblemente, el objetivo que teníamos. La propuesta me llegó por el 'Flaco' Marín (Pablo Alberto) que en ese momento era miembro del Secretariado de la Seccional Mendoza... ${ }^{74}$

Al preguntarle sobre la autoría de las notas, en su respuesta ofreció además una caracterización más amplia del colectivo al que pertenecía y el proceso de formación político-ideológico vivenciado por él y otros bancarios:

En efecto la revista era escrita por varios, y por disposición de Surballe -secretario Gral. de la Seccional Bancaria- las notas no iban firmadas, salvo la que escribí yo sobre Marlon Brando, en la que se me permitió poner mis iniciales. (...) No fuimos un grupo permanente en el sentido de constituir un comité de redacción, lo cual hubiera descentralizado algo el 'filtro' de Surballe y aliados (JP/Montos, en un principio, hasta que rompió con ellos en vísperas del juicio político al entonces gobernador: Martínez Baca. Pero este es otro tema). Las notas las escribíamos y las entregábamos a quien centralizaba el trabajo: Pablo Alberto Marín -desaparecido en el '79, posiblemente en Lanús; que era Secretario de Prensa-; que recuerde no tuvimos una reunión orgánica donde nos distribuyéramos el trabajo y se discutiera la orientación de la revista, el editorial, notas, etc. Acercándonos a una caracterización política, me parece que tanto la revista como los activistas bancarios que estábamos detrás de todo esto, éramos, de alguna manera, la expresión política de lo que se llama: 'radicalización a la izquierda de la pequeña burguesía' y por lo tanto de muchos colores y tintes políticos: foquistas, socialistas, clasismo revolucionario, peronistas, cristianos tercermundistas, etc. En general no teníamos experiencias políticas y la conciencia política era muy baja. No manejábamos mucha teoría política. Éramos más que todo activistas, es decir hacíamos sin tener análisis políticos más profundos. Por eso la JP/Montos tenía cierto peso. ${ }^{75}$.

Los datos de tiraje y distribución pueden resultar indicadores de la importancia que se le daba a esta herramienta. Otro delegado decía:

... se repartía masivamente, se hacía un ejemplar por cada trabajador (...) y en aquella época como 4000, más de 4000. Sí, se tiene que haber hecho por lo menos 3000 ejemplares de cada una. Y los delegados la llevaban a su banco y ahí la distribuían uno por uno. Y a su

\footnotetext{
${ }^{73}$ Idem.

${ }^{74}$ Entrevista a Felipe Cervine, op. cit.

75 Idem. .
} 
vez como las casas centrales estaban acá, vos tenías un servicio de bolsas con las sucursales. Entonces metías en la bolsa para que llegara a cada sucursal ${ }^{76}$.

Ahora bien: ¿qué temas, hechos son objeto de reflexión en DS? ¿sobre qué educar, formar, concientizar? Podemos hacer un primer análisis a partir de la composición de la revista ${ }^{77}$. Avanzando en los resultados, tenemos que en el $\mathrm{N}^{\circ} 1$ (mayo 1973), de un total de 33 notas $(100 \%)$, la mayoría refiere a aspectos sindicales (18 notas, es decir el 55\%); siguiendo las que tratan diversos temas de cultura general (9 notas, que representan el $27 \%$ ). Finalmente, los artículos referidos a temas de política nacional e internacional, representan $18 \%$, es decir 6 notas.

En el segundo y último número (octubre de 1973), disminuye la cantidad de notas $(28,100 \%)$. Si bien el eje sindical continúa teniendo centralidad (11 notas que representan el 39\% del total), la misma disminuye a favor de las notas referidas a la situación nacional (9 notas, es decir, 32\%). Aunque los artículos clasificados en el eje cultura general representan el 29\% (8 notas), en este número tienen menos densidad conceptual que en el $\mathrm{N}^{\circ} 1$ : se reitera un ingenioso horóscopo y predomina la reproducción de poemas, historietas, etc. Evidentemente la complejidad de los hechos políticos durante el breve lapso de mayo a septiembre, redefinió las prioridades y la necesidad de contar con más herramientas para leer la coyuntura que se atravesaba ${ }^{78}$.

Además de su extensión (cada número supera las 70 páginas), es importante destacar la densidad conceptual de la mayoría de las notas, las que a veces constituyen reseñas de libros, informes, o bien notas periodísticas con sugerencias de bibliografía ampliatoria. La decisión de incluir extensos artículos referidos a temas de actualidad y sobre la situación nacional o internacional, se argumenta con una explícita intención pedagógica. Por ejemplo, en una nota referida al Tercer Mundo y el concepto de liberación, se dice: 'Fieles a los enunciados que hemos formulado de no sólo 'informar' a los compañeros, sino también 'formar', suministrando material de discusión y que estimule al estudio"79

\footnotetext{
${ }^{76}$ Entrevista a Luis Piazza, op. cit.

77 Luego de una lectura global, identificamos 3 grandes ejes temáticos: sindical, política nacional $e$ internacional y cultura general. Pasamos así a agrupar las notas en cada uno de ellos según correspondiera, y luego contabilizamos para conocer la importancia relativa de cada uno.

${ }^{78}$ En este número se reflexiona sobre las medidas populares implementadas en 50 días por el gobierno; los hechos de Ezeiza, la renuncia de Cámpora, los ataques a los gobernadores de Bs. As., Mendoza y Córdoba; una reafirmación del proyecto socialista en los términos definidos por J.D. Perón y el señalamiento de que existen sectores al interior del gobierno popular que pretenden impedir ese proyecto. Por último, una afirmación que titula el artículo y lo cierra: El pueblo sabe lo que quiere. Casi al final se encuentra otra nota en la que se analiza la disyuntiva entre argentinización y estatización de los bancos nacionalizados. Referida también al debate político nacional, se reproduce una nota de R. Carpani punteando las características del Socialismo Nacional. La situación represiva tiene relevancia en este número, en dos amplias notas: una sobre la explotación y represión en Argentina, detallando formas y centros de tortura a nivel nacional y provincial. Y otra, más específica sobre la Masacre de Trelew que consta fundamentalmente de los testimonios de los tres sobrevivientes.

79 Revista Democracia Sindical N¹, Mayo 1973,9.
} 
No obstante la densidad teórica, las notas están escritas a partir de una lógica donde los aportes conceptuales se articulan con el análisis de otras experiencias del movimiento sindical, vinculándolos siempre a la propia situación de los bancarios mendocinos ${ }^{80}$, problematizando la visión corporativa que vería en esta amplitud temática un contenido ajeno a dicha situación ${ }^{81}$. La situación y el papel de la mujer en la sociedad contemporánea también es problematizada en la revista ${ }^{82}$, en la que hay un llamado a la participación de las bancarias como parte de la clase trabajadora ${ }^{83}$.

Pero como decíamos, no sólo se trata de la inclusión de otros contenidos sino de la lógica que los articula. En ese sentido, en su prosa predomina la primera persona del plural y una permanente interpelación directa a ese nosotros (nosotros los bancarios, nosotros la clase trabajadora) con el propósito de elaborar reflexiones y aprendizajes para la acción ${ }^{84}$.

Es desde ese lugar de interioridad con el conocimiento ${ }^{85}$ que se explican conceptos como "clasismo", "alienación", "Tercer Mundo", "liberación”, “enajenación", "nacionalización"/"estatización de la banca", "educación liberadora/educación bancaria", entre otros.

El humor, la poesía y el arte gráfico son otros recursos presentes en DS. En ambos números aparecía un "horóscoponzoñando" en el que, simulando predicciones astrológicas para cada signo el zodíaco, se reflexionaba irónicamente sobre distintos aspectos de la situación laboral y social de ese momento. Otro de los elementos significativos en sus páginas, es la presencia de lo cristiano a través de iconografías donde se muestra a un Cristo "explotado", encarnado en "el pueblo y sus luchas", el cual sería caracterizado por el sistema y sus autoridades como "subversivo" al posicionarse claramente por un proyecto: el de la "liberación". Aquí pueden reconocerse las huellas de la Teología de la Liberación,

\footnotetext{
${ }^{80}$ Lo que se ilustra en el siguiente artículo y su título: "Enajenación: un papel firmado cuando ingresamos al Banco", Democracia Sindical N $1,47-48$.

${ }^{81}$ Frente a esa visión, en primer lugar, se comenta que la decisión de incluir notas sobre la realidad nacional surgió por iniciativa de los propios compañeros; argumentando a favor de la misma al plantear que el bancario no es un "ser solitario", sino "profundamente humano, solidario y comprometido con su época, su mundo y los cambios que se registran y que no pueden ocultarse bajo un frustrado "humor individualista", Ver "La difusión de la revista superó nuestros cálculos", Revista Democracia Sindical N 2, Octubre $1973,5$. 82 "La mujer y el trabajo", Democracia Sindical N¹, óp. cit, 52. También en el N 2 se incluye una nota sobre la opresión de la mujer.

83 "Llamado a nuestras compañeras bancarias", Democracia Sindical № 1, óp. cit., 52.

${ }^{84}$ A modo de ejemplo, reseñamos los títulos de algunos artículos:

- "Firme postura sindical clasista de los bancarios peruanos”, Revista Democracia Sindical N¹, op.cit.,.4-5.

- "Reflexiones en torno a una conquista de los compañeros del BPS”, Revista Democracia Sindical N¹, op.cit.,. 32.

“Gerente de la SUC. Dorrego del Banco de Los Andes. Desafio para especialistas. ¿Es recuperable o no?”, Revista Democracia Sindical N², op.cit., 38-40, entre otros.

${ }^{85}$ Recuperamos los aportes de Verónica Edwards para el análisis de las formas de conocimiento, donde no sólo importa el contenido sino la relación con el mismo. Existe una relación de interioridad con el conocimiento, cuando el sujeto puede establecer una relación significativa con él, lo cual se produce cuando el conocimiento que se presenta incluye e interroga a ese sujeto. Ver Verónica Edwards, "Las formas de conocimiento en el aula", Elsie Rockwell (coord.) La escuela cotidiana. México, Fondo de Cultura Económica, 1995, 145-172.
} 
recreada por los activistas sindicales para reflexionar sobre la condición de asalariados y vincularla a la lucha por una transformación social, problematizando críticamente las caracterizaciones dominantes (como la que expresaba el término "subversión") a través del humor y la ironía.

Vinculado a lo anterior, recordemos que desde la década de 1960 en adelante, una de las expresiones del diálogo entre marxismo y cristianismo fue la recuperación/centralidad de la categoría de "Alienación" 86 , lo cual se vio reflejado en las nuevas lecturas realizadas desde el cristianismo. Dicha categoría no sólo estuvo presente, sino que articuló gran parte de la prosa de Democracia Sindical, siendo una de las herramientas conceptuales utilizadas para fundamentar las reflexiones sobre la condición socio-laboral de los bancarios y pensarse así como parte de un colectivo social más amplio: la clase trabajadora.

A modo de síntesis, es posible afirmar que tanto en los artículos sobre temas sindicales como culturales predomina una perspectiva política en el sentido de una permanente referencia y articulación de lo particular con lo general. Dicha perspectiva, además, problematizaba críticamente la realidad vigente y promovía la necesidad de un cambio hacia otro sistema que superara al capitalismo ${ }^{87}$.

\section{Conclusiones}

Si bien las Comisiones Internas (CI) son parte de la estructura sindical argentina, cuya actuación y funcionamiento se encuentran reglamentados en la legislación laboral, el caso estudiado permite observar que durante el período abordado, las mismas fueron impulsadas también de abajo hacia arriba; es decir, por el activismo de base que fue planteándose hacer suya la legalidad e institucionalidad vigente, como estrategia de construcción de mayores niveles de participación y poder por parte de los trabajadores para el logro de diversas conquistas. Aquí también tuvo importancia la organización política de los bancarios en distintas tendencias ideológicas: una suerte de heterogeneidad y pluralismo político que formaba parte de una larga tradición del gremio y que, hacia comienzos de los años setenta, fue decantando en nuevas corrientes y tendencias de la izquierda peronista y no peronista. Esa heterogeneidad, y el peso de diversas tendencias de izquierda, tal vez constituya una característica singular de este sector de los asalariados, que lo diferenciaba de otros sectores de la clase trabajadora argentina.

Otra característica importante refiere al nivel educativo alcanzado por estos trabajadores. En los años estudiados, hablamos de una fuerza laboral compuesta en un 50\% por sujetos jóvenes que habían comenzado estudios universitarios. En el $50 \%$ restante se ubicaba gran parte del personal de maestranza, ordenanza y también un sector del personal

\footnotetext{
86 Ver, Aranguren Sacristán Aguirre et.al., Cristianos y marxistas. Los problemas de un diálogo. Madrid, Alianza Editorial, 1969.

${ }^{87}$ Tal vez el título de la siguiente nota que clasificamos en el eje sindical resuma todos estos señalamientos: "La explotación del hombre por el hombre. Banco Unión Comercial e Industrial: fiel expresión local del sistema capitalista” Revista Democracia Sindical №2, óp. cit., 21.
} 
administrativo que habían completado, como máximo, el nivel primario. Los procesos de tecnificación y mecanización del sistema financiero se traducían en nuevas demandas de calificación de la fuerza laboral, que explican en parte la importancia que este gremio le otorgó a la educación en sus distintas formas y niveles.

En primer lugar se destaca la concepción amplia que existía en la AB sobre la educación: ésta abarcaba la propia práctica organizativa y toda una serie de iniciativas más o menos sistemáticas que iban desde cursos de capacitación sindical, charlas y conferencias, bibliotecas y revistas sindicales, etc.; hasta proyectos escolares vinculados de diversas maneras con el sistema educativo oficial, como fueron los Centros Educativos de Nivel Secundario o el intento aún inconcluso de fundar una "Universidad Sindical Bancaria".

El valor formativo de la práctica organizativa aparece como elemento central en los discursos de los delegados y activistas entrevistados, así como en la prosa de la revista Democracia Sindical de la seccional Mendoza. En ellos no sólo se recuperaba el aspecto organizativo sino además, y muy especialmente, el valor formativo de la lucha social: a través de ella los bancarios aprendían a reconocerse como parte de una clase, la de los trabajadores; aprendían a identificar a sus adversarios, las entidades patronales y la llamada "burocracia sindical"; aprendían el valor de la unidad y la organización, entre otros aprendizajes que explícitamente fueron reconocidos en sus intervenciones públicas en la prensa, durante las jornadas de lucha de marzo-abril de 1974, dinamizadas y conducidas por el Plenario de Comisiones Internas.

En tanto instrumento pedagógico, si bien la Revista Democracia Sindical enfatizaba los aspectos gremiales, observamos mayor peso de la teoría y de la reflexión sobre problemáticas políticas y culturales más amplias. No obstante, en todos los casos las notas están escritas a partir de una lógica donde los aportes conceptuales se articulan con el análisis de otras experiencias del movimiento sindical, vinculándolos siempre a la propia situación de los bancarios mendocinos. Se escribe desde y para una identidad colectiva, lo cual se advierte en la permanente interpelación directa a un nosotros (nosotros los bancarios, nosotros la clase trabajadora), con el propósito de elaborar reflexiones y aprendizajes para la acción, predominando así una relación de interioridad con el conocimiento. Otro aspecto que destacamos fue su perspectiva política, en el sentido de una permanente referencia y articulación de lo particular con lo general. El uso de la teoría, del humor y del arte gráfico tenía en las páginas de Democracia Sindical el propósito de hacer inteligible un mundo complejo y desigual, que demandaba una actuación comprometida por parte de sus lectores para transformarlo.

\section{Fuentes bibliográficas}

Acha, Omar, "Curso acelerado para el asalto de bancos", Alejandro Belkin (comp.) Relatos de luchas 1. Contribuciones a la historia del movimiento obrero, Editorial Desde El Subte, Buenos Aires. 2009, 9-27. 
Las huelgas bancarias de Perón a Frondizi (1945-1962). Contribución a la historia de las clases sociales en la Argentina, Ediciones del CCC, Buenos Aires. 2008, Aguirre, Aranguren Sacristán et.al., Cristianos y marxistas. Los problemas de un diálogo, Madrid, Alianza Editorial, 1969.

Baraldo, Natalia, Educación, organización de las clases subalternas y transformación social en Argentina. 1969-1976. Un análisis en casos. Tesis para optar al grado de Doctora en Ciencias de la Educación. Universidad Nacional de Córdoba, 2016.

Baraldo, Natalia, Evangelina Chinigioli, Miliagros Molina y Gabriela Scodeller, "La Escuela Sindical Bancaria: una experiencia de educación secundaria de adultos. Mendoza 1973/1976", Actas II Jornadas Internacionales de Problemas Latinoamericanos: Movimientos Sociales, Procesos Políticos y Conflicto Social: Escenarios de disputa. UNC, Córdoba, 18 al 20 de noviembre de 2010.

Baraldo, Natalia y Scodeller Gabriela (comps.) Mendoza'70. Tierra del Sol y de Luchas Populares. Buenos Aires, Manuel Suárez Editor, 2006.

Basualdo, Victoria, "Los delegados y las comisiones internas en la Historia Argentina: 1943-2007", Daniel Azpiazu et.at. La industria y el sindicalismo de base en la Argentina, Cara o Ceca, Buenos Aires, 2010, 81-157.

Edwards, Verónica, "Las formas de conocimiento en el aula", Elsie Rockwell (coord.) La escuela cotidiana. México, Fondo de Cultura Económica, 1995, 145-172.

Franco, Marina, "La 'depuración' interna del peronismo como parte del proceso de construcción del terror de Estado en la Argentina de la década del 70", A Contracorriente, Vol. 8, No. 3, 2011, 23 54, Disponible en www.ncsu.edu/project/acontracorriente. Visto en agosto de 2012.

Fiorenza, Néstor, Los trabajadores de cuello duro y la huelga bancaria de 1959, Editorial El Colectivo, Buenos Aires, 2011.

Kabat, Marina, Las condiciones laborales de los trabajadores bancarios argentinos, 1940 a la actualidad, $11^{\circ}$ Congreso Nacional de Estudios del Trabajo, Buenos Aires, UBA, agosto de 2013.

Michi, Norma; Di Matteo, Álvaro Javier y Vila, Diana, "Movimientos populares y procesos formativos", Polifonías. Revista de Educación. Año I, N¹, 2012, 22-41.

Onofrio, Sergio, Cambios en las relaciones y condiciones laborales en el sector bancario: el caso del Banco Mendoza. Mendoza, Universidad Nacional de Cuyo, Facultad de Ciencias Políticas y Sociales, Tesina de Licenciatura, inédita, 2003.

Ramírez, M. Carolina, Conflictividad social en Mendoza: el conflicto laboral en un sector clave de la economía. El caso bancario, Mendoza, Universidad Nacional de Cuyo, Facultad de Ciencias Políticas y Sociales,Tesina de Licenciatura, inédita, 2013.

Rodríguez Agüero, Laura, Ciclo de protestas, experiencias organizativas y represión paraestatal. Mendoza, 1972-1976, Tesis para optar al grado de Doctora en Historia. Universidad Nacional de La Plata, 2013.

Scodeller, Gabriela, Conflictos obreros en Mendoza (1969-1974): cambios en las formas de organización y lucha producto del Mendozazo. Un análisis del borramiento del conflicto como política de la memoria de la historiografía regional, Tesis de doctorado, Universidad Nacional de la Plata, 2009.

\section{Fuentes documentales}

Asociación Bancaria Nacional (1984) 60 años en la vida de un sindicato, sus hombres y el país. Bs. As. Secretariado General Nacional. 
Revista Democracia Sindical. Asociación Bancaria, seccional Mendoza. Año I, Nº1, Mayo 1973 y Año I, N², Octubre 1973.

Revista Claves para interpretar los hechos. Mendoza (1971-1973).

Diario MENDOZA, Mendoza (1970-1974).

Periódico ELECTRUM, órgano del Sindicato Luz y Fuerza, Córdoba (1973 y 1974).

\section{Fuentes orales}

Luis Ocaña. Entrevista realizada por Gabriela Scodeller, Mendoza, Julio de 2010 y Entrevista realizada por la autora, Mendoza, Mayo de 2011.

Luis Piazza. Entrevista realizada por la autora. Mendoza, Junio de 2011.

Héctor Orelogio. Entrevista realizada por la autora. Mendoza, Abril de 2012.

Felipe Cervine. Entrevista realizada por la autora (vía correo electrónico). Octubre de 2012 y Agosto de 2016.

Fabián Frontini. Secretaría de Cultura. Secretariado General Nacional de la Asociación Bancaria. Entrevista realizada por la autora. Buenos Aires, Septiembre de 2011.

Andrés Castillo, ex-delegado CGI de La Caja Nacional de Ahorro Postal. Entrevista realizada por la autora. Buenos Aires, Noviembre de 2011.

Eduardo Berrozpe, ex delegado CGI Banco Avellaneda de Buenos Aires. Entrevista telefónica realizada por la autora. Buenos Aires, Julio de 2011. 